\title{
SHORT-TERM PHYTOPLANKTON DYNAMICS IN RESPONSE TO TIDAL STIRRING IN A TROPICAL ESTUARY (SOUTHEASTERN BRAZIL)
}

\author{
Suzana Gonçalves Leles ${ }^{1, *}$, Catharina Alves de Souza ${ }^{2}$, Cassia de Oliveira Faria ${ }^{3}$, Ana Beatriz Ramos ${ }^{3}$, \\ Alexandre Macedo Fernandes ${ }^{4}$ and Gleyci Aparecida de Oliveira Moser ${ }^{I}$ \\ ${ }^{1}$ Universidade Estadual do Rio de Janeiro - Faculdade de Oceanografia \\ Departamento de Oceanografia Biológica \\ (Rua São Francisco Xavier, 524, 20550-900 Rio de Janeiro, RJ, Brasil) \\ ${ }^{2}$ Museu Nacional - Universidade Federal do Rio de Janeiro \\ Departamento de Botânica \\ (Quinta da Boa Vista, s/n, 20940-040 Rio de Janeiro, RJ, Brasil) \\ ${ }^{3}$ Universidade Estadual do Rio de Janeiro - Faculdade de Oceanografia \\ Departamento de Oceanografia Química \\ (Rua São Francisco Xavier, 524, 20550-900 Rio de Janeiro, RJ, Brasil) \\ ${ }^{4}$ Universidade Estadual do Rio de Janeiro - Faculdade de Oceanografia \\ Departamento de Oceanografia Física \\ (Rua São Francisco Xavier, 524, 20550-900 Rio de Janeiro, RJ, Brasil) \\ *Corresponding author: suzanaleles@gmail.com
}

http://dx.doi.org/10.1590/S1679-87592014070506204

Descriptors: Tropical estuary, Tidal stirring, Phytoplankton.

Descritores: Estuário tropical, Movimento da maré, Fitoplâncton.

The spatio-temporal distribution of phytoplankton assemblages can be highly affected by physical, chemical and biological processes (HANSSON, 1995; MACINTYRE; CULLEN, 1996; SEURONT et al., 2001). Estuaries are highly variable environments and the processes listed above can influence phytoplankton dynamics not only seasonally (MACEDO et al., 2001; IGNATIADES et al., 2002) but also during tidal cycles (GOOSEN et al., 1999; BRUNET; LIZON, 2003). Tidal stirring constitutes a relevant driving force affecting phytoplankton distribution, since it induces substantial horizontal and vertical mixing of the water column, as well as upstream and downstream displacement of water masses along the main longitudinal estuarine axis. While horizontal mixing has more mechanical effects on phytoplankton (LEGENDRE; DEMERS, 1984), vertical mixing can affect phytoplankton physiology and growth due to its strong impact on the availability of nutrients and light (DEMERS et al., 1979).

Overall, tidal forcing is responsible for short-term changes in phytoplankton biomass, specific composition, growth and primary production (WETZ et al., 2006). These effects are especially important in shallow tidally-driven estuarine systems (CLOERN, 1991; WETZ et al., 2006) and different authors have been studying patterns of primary production on this time scale (JOUENNE et al., 2005; HELBLING et al., 2010), but it is also interesting to get some insights on changes in phytoplankton composition (BUCCI et al., 2012; MOSER et al., 2012).

Due to its polyphyletic origin, phytoplankton show distinct physiological behavior as well as different abiotic requirements for growth (MARGALEF, 1978; SEIP; REYNOLDS., 1995; LICTHMAN; KLAUSMEIER, 2008). The phytoplankton community composition as well as the spatial and temporal distribution of the species would likely be better understood when considering the physiology as a reflex of their morphometric characteristics (REYNOLDS, 1988; REYNOLDS et al., 2002). Cell size (maximum linear dimension; $\mathrm{MDL}$ ), surface/volume ratio (S/V) and cell shape are excellent tools to investigate such patterns (LEWIS, 1976; SOURNIA, 1982; MCGILL et al., 2006). REYNOLDS (1988, 2002) applied a functional classification for freshwater phytoplankton using morphological traits (MLD and S/V ratio), proposing the C-S-R strategies, based on Grime's Competitors, Stress-tolerants and Ruderals (CSR) triangle model for terrestrial plants, and identified three strategies among phytoplankton species. In natural environments, the form and size selection can be the major force that drives phytoplankton communities under distinct 
environmental conditions (NASELLI-FLORES et al., 2007), which is why the Reynolds strategies were used in this study. Although developed for freshwater phytoplankton, this classification has been successfully tested for marine phytoplankton (e.g. SMAYDA; REYNOLDS, 2001; ALVES-DE-SOUZA et al., 2008; MOSER et al., 2014), and the present study is a contribution to the theme in tropical estuaries. Therefore, the aim of this study was to characterize the dynamics of phytoplankton assemblages focusing on the short-term temporal variations associated with tidal stirring, haline gradients and nutrient concentrations, showing preliminary results of the phytoplankton community composition of the Barra Grande estuary (Ilha Grande, Southeastern Brazil), focusing on morphological traits. It is worthy of note that this is the first study on phytoplankton ecology in Barra Grande estuary.

Ilha Grande is located between Ilha Grande Bay and Sepetiba Bay (Fig. 1). The Barra Grande estuary (Vila Dois Rios, Ilha Grande) was selected for this study because it can be considered a mesocosm due to its shallow depths (around $3 \mathrm{~m}$ ), its average 80 $\mathrm{km}$ length, $10 \mathrm{~m}$ width and single freshwater source, thus resembling the classic estuary defined by PRITCHARD (1956). Studies in natural systems such as the Barra Grande estuary are interesting because this latter presents the simplicity and small size of a mesocosm without the manipulating conditions of an artificial system. Besides, the Barra Grade estuary has been poorly studied and is subject to low anthropogenic influence due to its location in one of the most preserved portions of Atlantic Rainforest of Rio de Janeiro state.

The survey was conducted in March/2012, (austral summer; rainy season) in a mooring $\left(23^{\circ} 11^{\prime} \mathrm{S}\right.$ and $\left.44^{\circ} 12^{\prime} \mathrm{W}\right)$ during a complete tidal cycle in spring tide. Two tidal rulers were positioned near the mooring to verify the tidal variation and the Secchi depth was obtained during the survey. The current data were obtained by an ADCP (Aquadopp high resolution Nortek S.A.; frequency $2 \mathrm{MHz}$ ) and a CTD (SBE, model 19 plus V2 SEACAT; frequency $4 \mathrm{~Hz}$ ) was used to obtain profiles of temperature and salinity at intervals of an hour. The data were processed on MatLab (R2008a). The Barra Grande estuary was classified by the Stratification-Circulation Diagram of HANSEN AND RATTRAY (1966) and in accordance with MIRANDA et al. (2002).

Phytoplankton and nutrient samples were collected with a Van Dorn bottle at intervals of one hour and half an hour, respectively, at the surface and near the bottom. Nutrient analyses were carried out by spectrophotometric methods (HANSEN; KOROLEFF, 1983, for phosphate, nitrate, nitrite and ammonium determination). Phytoplankton samples were kept in the dark to preserve algal pigments, in $250 \mathrm{~mL}$ flasks, preserved with $4 \%$ formaldehyde.

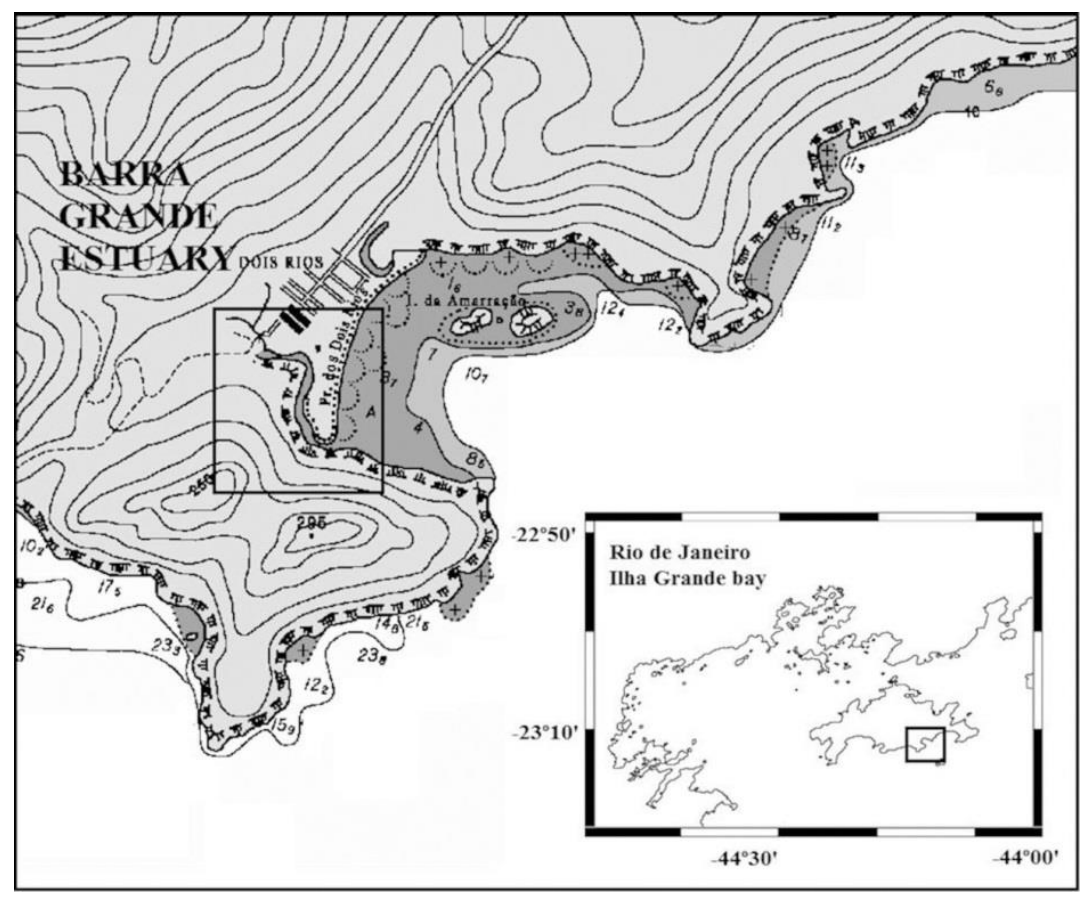

Fig. 1. Study area located between Ilha Grande Bay and Sepetiba Bay (Ilha Grande, RJ, Brazil). 
An inverted optical microscope was used to determine phytoplankton cell density, under an amplification of $400 \mathrm{x}$, in sedimentation chambers of $100 \mathrm{~mL}$ (UTERMÖHL, 1958). Cell counts were carried out on transects, and whereas a minimum of 400 cells was required for nanophytoplankton $(2-20$ $\mu \mathrm{m}), 200$ cells were required for microphytoplankton (20 - $200 \mu \mathrm{m})$, in accordance with LUND et al. (1964), CUPP (1943) and TOMAS (1997). Phytoplankton biovolume was calculated assuming the geometrical form of the cell (HILLEBRAND et al., 1999; SUN; LIU, 2003; OLENINA et al., 2006) and then converted to carbon using linear regressions obtained from the literature (STRATHMANN, 1967 for diatoms; VERITY et al., 1992 for nanophytoplankton; and MENDEN-DEUER; LESSARD, 2000 for dinoflagellates and chlorophytes).

To classify the phytoplankton according to C-S-R strategies (REYNOLDS, 1988), taxa were selected by the following criterion: $10 \%$ of abundance in at least $50 \%$ of the observations. This criterion was applied separately for diatoms, dinoflagellates and other groups (cyanobacterias, chlorophytes, euglenophyceaes and phytoflagellates $<20 \mu \mathrm{m}$ ), due to high diatom abundance in all the samples.

To analyze the main variables that influence species distribution in space and time we used multivariate analysis. In order to test if the groups formed by the C-S-R strategies were significantly different we first ordered the species by their $\mathrm{S} / \mathrm{V}$ ratio using multidimensional scaling (MDS) and then ran an ANOSIM test using the computer program PRIME (version 7, for Windows). All these tests were applied to the previously normalized $[\log (x+1)]$ biotic dataset (26 descriptors $\mathrm{x} 12$ variables). A canonical correspondence analysis (CCA) was applied to the abiotic (26 descriptors $\times 8$ variables) and the biotic datasets using CANOCO (Windows version). The statistical significance of the amount of variance added by each variable was tested by the Monte Carlo permutation test, using 999 permutations $(p=0.05)$; only significant variables were included. The normalized data were also subjected to one-way analysis of variance (ANOVA) for depth (surface and bottom) and related variables (current speed, temperature, salinity and cell density).

The Barra Grande estuary is dominated by semi-diurnal tides with well-defined flood and ebb cycles. The consecutive high water levels exhibited a difference of about $0.2 \mathrm{~m}$, indicating diurnal inequality. The local depth varied between 2 and 3.5 $\mathrm{m}$. There was no difference between Secchi depth and local depth at any time during the experiment, indicating that light was able to reach the bottom. Temperature was higher on the surface (maximum of $27.2^{\circ} \mathrm{C}$ ), the opposite was observed for salinity (Table 1). Current speeds were very low near the bottom, except at flood tide, when values were around $0.1 \mathrm{~m} \mathrm{~s}^{-1}$. On the surface, current speeds were higher, especially at ebb tide (maximum of $0.3 \mathrm{~m} \mathrm{~s}^{-1}$ ). These values and the fact that the ebb tide was longer than the flood tide (one hour and a half), indicate that the river discharge plays an important role in the estuary dynamics. The estuary was classified as type 2 according to the Stratification-circulation Diagram, highly stratified, where the resulting flow reverses with depth and the advective and dispersive processes are important to the transport of salt up the estuary. Similar results were found for the estuarine system of Cananéia-Iguape and for Guanabara Bay (BÉRGAMO et al., 2008).

Table 1. Mean and standard deviation (SD) of environmental variables data.

\begin{tabular}{lllll}
\hline \hline & \multicolumn{2}{c}{ Surface } & \multicolumn{2}{c}{ Bottom } \\
\hline & mean & SD & mean & SD \\
Temperature $\left({ }^{\circ} \mathrm{C}\right)$ & 25.9 & 0.87 & 24.9 & 1.36 \\
Salinity & 25.98 & 4.88 & 31.81 & 2.09 \\
Density $\left(\mathrm{kg} \mathrm{m}^{-3}\right)$ & 1017.59 & 2.86 & 1020.9 & 1.87 \\
Current speed $\left(\mathrm{m} \mathrm{s}^{-1}\right)$ & 0.02 & 0 & -0.01 & 0 \\
$\mathrm{NO}_{3}^{-}\left(\mu \mathrm{mol} \mathrm{L}^{-1}\right)$ & 6.4 & 2.23 & 1.56 & 1.17 \\
$\mathrm{NO}_{2}^{-}\left(\mu \mathrm{mol} \mathrm{L}^{-1}\right)$ & 2.23 & 0.05 & 1.17 & 0.03 \\
$\mathrm{Si}\left(\mu \mathrm{mol} \mathrm{L}^{-1}\right)$ & 107.4 & 46.7 & 42.4 & 29.9 \\
$\mathrm{PO}_{4}^{-}\left(\mu \mathrm{mol} \mathrm{L}^{-1}\right)$ & 0.07 & 0.04 & 0.13 & 0.17 \\
$\mathrm{Chl}^{-\mathrm{a}}\left(\mathrm{mg} \mathrm{m}^{-3}\right)$ & 1.45 & 1.12 & 7.25 & 7.04 \\
\hline
\end{tabular}

The mean values and the standard deviation of nutrient concentrations are represented in table 1 . Generally, higher concentrations of inorganic nutrients were observed in surface waters during the ebb tide. Phosphate and nitrite concentrations were low during the survey due to the well preserved state of the area and because the latter is an intermediate and unstable form of the nitrogen cycle. Silicate concentrations oscillated during the tidal cycle reaching maximum values at the surface during ebb tide $\left(36.06 \mu \mathrm{mol} \mathrm{L}^{-1}\right.$ -

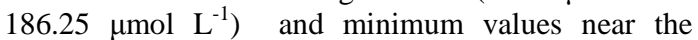
bottom during flood tide $\left(17.96 \mu \mathrm{mol} \mathrm{L} \mathrm{L}^{-1}-86.21 \mu \mathrm{mol}\right.$ $\left.\mathrm{L}^{-1}\right)$, just as the concentrations of ammonium and nitrate. Ammonium concentrations varied from 2.01

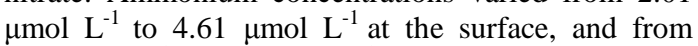
$1.31 \mu \mathrm{mol} \mathrm{L} \mathrm{L}^{-1}$ to $9.8 \mu \mathrm{mol} \mathrm{L} \mathrm{L}^{-1}$ near the bottom. Nitrate variation was related to tides, presenting higher values on the ebb tide and lower values on the flood tide (1.9 $\mu \mathrm{mol} \mathrm{L} \mathrm{L}^{-1}$ and $10.38 \mu \mathrm{mol} \mathrm{L}{ }^{-1}$ at the surface; $0.5 \mu \mathrm{mol}$ $\mathrm{L}^{-1}$ and $4.33 \mu \mathrm{mol} \mathrm{L}{ }^{-1}$ near the bottom).

The concentration of chlorophyll- $a$ (Chl- $a$ ) was higher near the bottom, reaching a maximum of $30.36 \mathrm{mg} \mathrm{m}^{-3}$ on the flood tide, together with a higher current speed at this depth, indicating phytoplankton resuspension, since the phytoplankton community was dominated by raphid pennate diatoms. This maximum 
was not observed at the surface due to the water column's haline stratification. Values of Chl- $a$ between 2 and $10 \mathrm{mg} \mathrm{m}^{-3}$ are commonly observed in coastal regions, as for example in the Cananéia-Iguape estuarine system where concentrations varied from 2.74 a $5.71 \mathrm{mg} \mathrm{m}^{-3}$ in January/2001 (BARRERAALBA et al., 2007).

Phytoplankton cell density varied from $10^{4}$ to $10^{6}$ cell $\mathrm{L}^{-1}$. Generally, density was higher near the bottom, as observed for concentrations of Chl- $a$. Light seemed to be non-limiting for phytoplankton growth during the sampling. Most of the species found in the Barra Grande estuary were marine and neritic, probably resulting from cell importation from the adjacent shelf, as well as from local production. The mean cell density observed in Barra Grande estuary was $5.7 \times 10^{5}$ cell $\mathrm{L}^{-1}$. On the study carried out on Cananéia-Iguape the mean cell density was $2.3 \times 10^{6}$ cell $\mathrm{L}^{-1}$ in the estuary and $1.8-1.7 \times 10^{6}$ cell $\mathrm{L}^{-1}$ near the connections with the ocean (BARRERA-ALBA et al., 2007). In Guanabara Bay, cell density varies between $10^{5}-10^{9}$ cell $\mathrm{L}^{-1}$ (VILLAC; TENENBAUM 2010). Phytoplankton is responding with higher densities to eutrophication in these estuarine systems, which differ in their geomorphology as well as in the anthropogenic pressure and nutrient sources (PARANHOS et al., 1998; SOUZA et al., 2012).

As expected in coastal systems (TREMBLAY et al., 1997; MURREL, 2004; VARGAS et al., 2007), nanophytoplankton contributed more to the total phytoplankton than did microphytoplankton, representing $77 \%$ of total phytoplankton cells on the surface and $61 \%$ near the bottom. This lower relative contribution near the bottom was due to the high density of microphytoplanktonic forming chains diatoms. These diatoms were found at both depths, but near the bottom the diatoms and chains were much longer. This pattern can be explained by the sinking rate of the chain, which increases proportionally to chain length (SOURNIA, 1982). Diatoms contributed with more than $85 \%$ of the microphytoplankton throughout the tidal cycle. Dinoflagellates made a mean contribution of $3 \%$ on the surface and $6 \%$ near the bottom, due to the presence of species with benthonic habits (Order Prorocentrales) (TOMAS, 1997). The other groups, represented especially by phytoflagellates but also by cyanobacteria and chlorophytes presented a higher contribution near the bottom during the flood tide maximum high, corresponding to $9 \%$ of the microphytoplankton. A complete list of the taxa identified in this study is presented in Table 2.

Species richness was high at both depths, with a mean value of 28 species. On the surface, the higher values (34) corresponded to the ebb tide and its maxima. At the bottom, the higher values
(44) occurred during the flood tide maximum high. These results can be linked to the higher current speed at both depths, probably contributing to the importation of cells and the mixture of water masses (marine and freshwater). The higher current speed provides physical disturbance, which according to the "intermediate disturbance hypothesis" prevents competitively dominant species from excluding other species from the community, and so increasing the species richness (GRIME, 1973; CONNEL 1978). Diversity and evenness were low at both depths, indicating that some species dominate the phytoplankton community. The most abundant species were Leptocylindrus minimus, Leptocylindrus danicus, Guinardia spp, Dactyliosolen fragilissimus, Skeletonema costatum and species of the Pseudonitzschia complex.

Phytoplankton biomass varied between $6.2 \mu \mathrm{gC} \mathrm{L} \mathrm{L}^{-1}$ and $93 \mu \mathrm{gC} \mathrm{L} \mathrm{L}^{-1}$ (Fig. 2) with a mean of $29.5 \mu \mathrm{gC} \mathrm{L}^{-1}$. The values were higher near the bottom, reaching a maximum during the flood tide, together with the maximum values found for cell density. The minimum was observed during the ebb tide $(7.8 \mu \mathrm{gC}$ $\left.\mathrm{L}^{-1}\right)$. At the surface, biomass varied from $33.55 \mu \mathrm{gC}$ $\mathrm{L}^{-1}$ during flood tide to $6.23 \mu \mathrm{gC} \mathrm{L}^{-1}$ during ebb tide. The values found for the Cananéia-Iguape system (BARRERA-ALBA et al., 2007) were superior, reaching $284 \mu \mathrm{gC} \mathrm{L}^{-1}$ inside the estuary and $199 \mu \mathrm{gC}$ $\mathrm{L}^{-1}$ in the connection with the ocean. Again, these results can be explained because Cananéia-Iguape is an eutrophic estuary.

Despite the clear dominance of diatoms during this survey (diatom densities were 40 times higher than those of dinoflagellates densities), dinoflagellates contributed considerably in terms of biomass, since diatom biomass was only twice greater than that of the dinoflagellates. These results are observed because a single cell of a dinoflagellate contains much more carbon per volume than a single cell of a diatom (e.g. Prorocentrum, $2283.8 \mathrm{pgC} \mathrm{L}^{-1}$; Leptocylindrus danicus, $25.7 \mathrm{pgC}^{-1}$ ). This may be due the presence of vacuoles in the cell structure of many diatoms (STRATHMANN, 1967).

Among the 116 identified taxa, only fourteen were selected by their frequency and abundance for the C-S-R approach (Table 3). They differed in size and form, the $\mathrm{S} / \mathrm{V}$ ratio of these species varied from 0.07 to $2.25 \mu^{-1}$. Figure 2 shows that taxa were distributed among the strategies independently of their phylogenetic relations. As expected for estuarine and coastal systems (see BONILLA et al., 2005), Rstrategists $(55 \%)$ and S-strategists $(41 \%)$ dominated the study area, and only one taxon was classified as Cstrategist (4\%). Ruderals were represented by: Pseudonitzschia Complex, Leptocylindrus minimus, Leptocylindrus danicus, Skeletonema cf. costatum, Guinardia, Dactyliosolen fragilissimus and 
cyanobacteria. These organisms are elongated and despite their huge dimensions, have high $\mathrm{S} / \mathrm{V}$ ratios. This feature contributes to their development under low light conditions, but they need high nutrient concentration and turbulence to develop. C-strategists were represented only by Navicula sp, which presented small cells, with high growth rates and S/V ratio, and $S$-strategists represented by the dinoflagellates and the chlorophytes. S-strategists are characterized by low $\mathrm{S} / \mathrm{V}$ ratio, mixotrophy and the ability to undertake vertical migration, this strategy being dominant in oligotrophic systems (REYNOLDS, 1988). SMAYDA and REYNOLDS (2001) identified nine life-forms among C-S-R strategies in different marine habitats. The present study was limited to one habitat, thus all dinoflagellates were classified as S-strategists according to life-form type II (Peridinians/Prorocentroids), in other words summer bloom taxa, such as Scrippsiella trochoidea and Prorocentrum micans, identified here and present in habitats with substantially elevated nutrient concentration.

Table 2. List of identified taxa in Barra Grande estuary, Rio de Janeiro (Brazil).

\begin{tabular}{|c|c|c|}
\hline \multicolumn{3}{|c|}{ Mean density (cell $\left.\mathrm{L}^{-1}\right)$ and mean frequence $(\%)$} \\
\hline Taxon & $\begin{array}{c}\text { Mean } \\
\text { Density }\end{array}$ & $\begin{array}{l}\text { Mean } \\
\text { frequence }\end{array}$ \\
\hline \multicolumn{3}{|l|}{ Diatoms } \\
\hline Anaulus australis & 255 & 0,12 \\
\hline Chaetoceros spp & 10 & 0,02 \\
\hline $\begin{array}{l}\text { Cylindrotheca closterium/Nitzschia } \\
\text { longissima complex }\end{array}$ & 1623 & 1,40 \\
\hline $\begin{array}{l}\text { Cylindrotheca closterium/Nitzschia } \\
\text { reversa complex }\end{array}$ & 198 & 0,21 \\
\hline Diploneis-Raphoneis complex & 1823 & 1,49 \\
\hline $\begin{array}{l}\text { Pseudo- } \\
\text { nitzschia } \text { cf. delicatissima complex }\end{array}$ & 7762 & 3,58 \\
\hline Pseudo-nitzschia complex & 3975 & 2,67 \\
\hline Pseudo-nizschia seriata complex & 4890 & 2,95 \\
\hline Raphoneis spp & 405 & 0,28 \\
\hline Cyclotella spp & 225 & 0,17 \\
\hline Cylindrotheca cf. closterium & 5392 & 4,71 \\
\hline Dactyliosolen cf. phuketensis & 621 & 0,20 \\
\hline Dactyliosolen fragillissimus & 18326 & 9,95 \\
\hline Diploneis cf. crabro & 10 & 0,02 \\
\hline Diploneis spp & 22 & 0,04 \\
\hline Eucampia cf. zodiacus & 82 & 0,02 \\
\hline Tropidoneis spp & 229 & 0,23 \\
\hline Guinardia cf. cylindrus & 344 & 0,24 \\
\hline Guinardia cf. flaccida & 814 & 0,29 \\
\hline Guinardia delicatula & 14347 & 5,89 \\
\hline Guinardia spp & 313 & 0,23 \\
\hline Guinardia striata & 4493 & 1,71 \\
\hline Gyrosigma cf. fasciola & 78 & 0,16 \\
\hline Gyrosigma spp & 68 & 0,05 \\
\hline Helicotheca spp & 169 & 0,06 \\
\hline Leptocylindricus cf. danicus & 40971 & 18,60 \\
\hline Leptocylindricus cf. minimus & 54357 & 23,10 \\
\hline
\end{tabular}

Licmophora spp $\quad 221$

Lioloma spp

Manguinea cf. fusiformis

Manguinea $\mathrm{cf}$. rigida

Manguinea spp

Meuniera membranaceae

Navicula cf. directa

Navicula cf. transitans var derasaf.

delicatula

Navicula spp

Paralia sulcata

Pleurosigma riscada

Pleurosigma spp

Pseudo Guinardia cf. recta

Rhizosolenia cf. hebetata

Rhizosolenia cf. imbricata

Rhizosolenia cf. setigera

Rhizosolenia $\mathrm{cf}$. styliformis

Rhizosolenia spp

Skeletonema cf. costatum

Thalassionema $\mathrm{spp}$

Thalassioonema cf. nitzschioides

Thalassiosira spp

Non-identified centric diatoms

Non-identified pennate diatoms

\section{Dinoflagellates}

Alexandrium spp

Dinophysis cf. acuminata

Gonyaulax spp

Gymnodinium spp

Gyrodinium spp

Heterocapsa cf. triquetra

Heterocapsa spp

Prorocentrum balticum

Prorocentrum cf. compressum

Prorocentrum cf. concavum

Prorocentrum cf. gracile

Prorocentrum $\mathrm{cf}$. micans

Prorocentrum cf. pelucidum

Prorocentrum spp

Protoperidinium cf. brevipes

Protoperidinium cf. claudicans

Protoperidinium cf. leonis

Protoperidinium cf. steinii

Protoperidinium spp

Scrippsiella cf. trochoidea

Scrippsiella spinifera

Non-identified athecate dinoflagellates

Non-identified thecate dinoflagellates

\section{Other Groups}

Anabaena spp

Chroococcus sp. 1

Chroococcus sp. 2

Chlorophyte sp.1

Chlorophyte sp. 2

Chlorophyte sp. 3

Chlorophyte sp. 4

Cyanobacteria

Dictyocha fibula

Eutreptiella cf. lowonii

Eutrepptiella cf. marina

Merismopedia spp

Filamentous Cyanobacteria

Unidentified

$\begin{array}{ll}31 & 0,02 \\ 82 & 0,02 \\ 176 & 0,05 \\ 13 & 0,02 \\ 136 & 0,02 \\ 318 & 0,13 \\ 102 & 0,02 \\ 82 & 0,02 \\ 15 & 0,04 \\ 133 & 0,04 \\ 41 & 0,04 \\ 472 & 0,11 \\ 9 & 0,02 \\ 13 & 0,02 \\ 23 & 0,06 \\ 95 & 0,04 \\ 163 & 0,04 \\ 544 & 0,07 \\ 2025 & 0,71 \\ 800 & 0,25 \\ 684 & 0,44 \\ 187 & 0,11 \\ 862 & 0,40\end{array}$

$\begin{array}{ll}219 & 0,17 \\ 27 & 0,04 \\ 0 & 0,00 \\ 10 & 0,02 \\ 16 & 0,04 \\ 6 & 0,02 \\ 343 & 0,10 \\ 34 & 0,08 \\ 173 & 0,06 \\ 43 & 0,10 \\ 2151 & 0,70 \\ 417 & 0,12 \\ 608 & 0,21 \\ 343 & 0,32\end{array}$




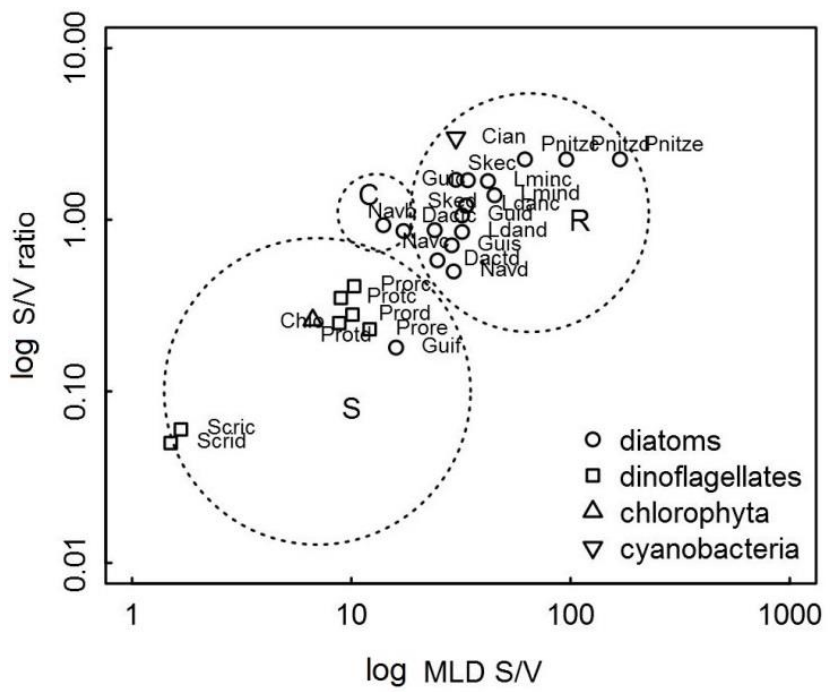

Fig. 2. Distribution of the fourteen taxa selected for the classification in C-S-R strategies determined by their S/V ratio and the product of their MLD and S/V. The codes of the species are the same as in table 3. S/V ratio in $\mu \mathrm{m}^{-1}$.

Statistical analyses showed that the C-S-R strategists described above differ significantly (ANOSIM test: $\mathrm{R}=0.75 ; \mathrm{p}=0.001$ ). This result indicates that the morphological trait-based approach is useful for describing the phytoplankton community, as stated above (SOURNIA, 1982; REYNOLDS, 1988; LITCHMAN; KLAUSMEIER, 2008). The CCA showed that the pattern observed at the surface differs from that at the bottom, and showed clear differences between the variables that regulate the distribution of the $\mathrm{R}$ and the $\mathrm{S}$ species (Fig. 3). $\mathrm{R}$ species were associated with nutrients (ebb tide) whereas $\mathrm{S}$ species were associated with rapid current and salinity (flood tide). The first group needs high nutrient concentrations to develop and the second group (mainly dinoflagellates) composed of marine species, live in association with the bottom, thus explaining their correlation with current speed and higher salinity (Fig. 3).

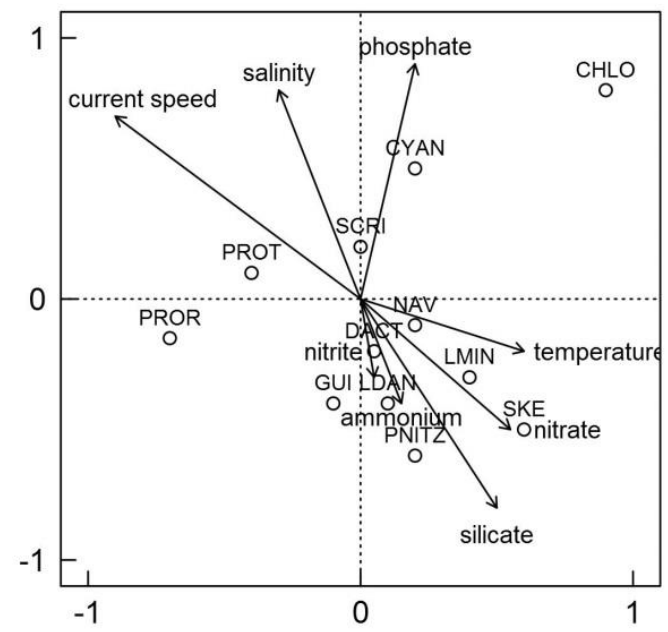

Fig. 3. Canonical Correspondence Analysis (CCA). Ruderal taxa are related with higher values of nutrients concentration (ebb tide) and stress-tolerants taxa are related with higher values of salinity and current speed (flood tide). See codes on Table 3. 
Table 3. Selected species for functional classification and their main characteristics. MLD $(\mu \mathrm{m})$ - maximum linear dimension; SA $(\mu \mathrm{m} 2)$ - surface area; BV $(\mu \mathrm{m} 3)$ - biovolume.

\begin{tabular}{|c|c|c|c|c|c|c|}
\hline Diatoms & Code & Cell Shape & MLD & SA & BV & $\mathrm{S} / \mathrm{V}$ \\
\hline \multirow[t]{2}{*}{ Leptocylindrus cf. minimus } & Lminc & cylinder & 25 & 206.06 & 122.66 & 1.68 \\
\hline & Lmind & cylinder & 32.5 & 320.28 & 229.61 & 1.39 \\
\hline \multirow[t]{2}{*}{ Leptocylindrus cf. danicus } & Ldanc & cylinder & 27.5 & 321.46 & 264.45 & 1.22 \\
\hline & Ldand & cylinder & 37.5 & 628 & 735.94 & 0.85 \\
\hline \multirow[t]{2}{*}{ Dactyliosolen cf. fragilissimus } & Dactc & cylinder & 27.5 & 471 & 539.69 & 0.87 \\
\hline & Dactd & cylinder & 42.5 & 1089.19 & 1876.64 & 0.58 \\
\hline \multirow[t]{2}{*}{ Guinardia delicatula } & Guidb & cylinder & 17.5 & 147.19 & 85.86 & 1.71 \\
\hline & Guidc & cylinder & 30 & 401.92 & 376.8 & 1.07 \\
\hline Guinardia striata & Guis & cylinder & 40 & 810.12 & 1130.4 & 0.72 \\
\hline Guinardia flaccida & Guif & cylinder & 87.5 & 7850 & 42929.69 & 0.18 \\
\hline \multirow[t]{2}{*}{ Skeletonema cf. costatum } & Skeb & cylinder & 20 & 166.81 & 98.13 & 1.7 \\
\hline & Skec & cylinder & 27.5 & 321.46 & 264.45 & 1.22 \\
\hline \multirow[t]{3}{*}{ Pseudo-nitzschia complex } & Pnitzc & $\begin{array}{l}\text { prism on } \\
\text { parallelogram-base }\end{array}$ & 27.5 & 61.89 & 27.5 & 2.25 \\
\hline & Pnitzd & $\begin{array}{l}\text { prism on } \\
\text { parallelogram-base }\end{array}$ & 42.5 & 95.64 & 42.5 & 2.25 \\
\hline & Pnitze & $\begin{array}{l}\text { prism on } \\
\text { parallelogram-base }\end{array}$ & 75 & 168.76 & 75 & 2.25 \\
\hline \multirow[t]{3}{*}{ Navicula spp. } & $\mathrm{Navb}$ & prism on elliptic base & 15 & 274.75 & 294.38 & 0.93 \\
\hline & Navc & prism on elliptic base & 20 & 408.2 & 471 & 0.87 \\
\hline & Navd & prism on elliptic base & 42.5 & 1361.98 & 2001.75 & 0.68 \\
\hline \multicolumn{7}{|l|}{ Dinoflagellates } \\
\hline \multirow[t]{2}{*}{ Protoperidinium spp. } & Protc & double cone & 25 & 1188.12 & 3311.72 & 0.36 \\
\hline & Protd & double cone & 35 & 2437.08 & 9673.49 & 0.25 \\
\hline \multirow[t]{2}{*}{ Scrippsiella spp. } & Scric & ellipsoid & 25 & 441.56 & 6623.44 & 0.07 \\
\hline & Scrid & ellipsoid & 27.5 & 593.66 & 10883.7 & 0.05 \\
\hline \multirow[t]{3}{*}{ Prorocentrum spp. } & Prorc & cone & 25 & 1365.83 & 3311.72 & 0.41 \\
\hline & Prord & cone & 35 & 2798.13 & 9673.49 & 0.29 \\
\hline & Prore & cone & 55 & 4133.17 & 17629.79 & 0.23 \\
\hline \multicolumn{7}{|l|}{ Other Groups } \\
\hline Cyanobacteria & Cyan & sphere & 10 & 12.56 & 4.19 & 3 \\
\hline Chlorophyta & Chlo & sphere & 25 & 1589.63 & 5961.09 & 0.27 \\
\hline
\end{tabular}

To better understand the phytoplankton community of Barra Grande estuary, it is important to investigate more tidal cycles as well as the seasonal temporal distribution. Nevertheless, this is the first published data on the phytoplankton community of Ilha Grande Bay, a touristic area of Rio de Janeiro state containing more than 10 protected areas, which justifies the importance of monitoring biological data. Because of the absence of previous data, the results presented here were compared to those of other tropical estuaries influenced by rainforest, such as Guanabara Bay and the estuarine system CananeiaIguape, already frequently studied specially due to the eutrophication process. 
This study is part of the OTRANSCO (Organic Carbon Origin and Transport in Barra Grande Estuary) project, granted by FAPERJ.

\section{ACKNOWLEDGMENTS}

This work was supported by FAPERJ (Foundation for Research Support of Rio de Janeiro state) and is part of the OTRANSCO project. We wish to thank the people who helped during sampling operations and to acknowledge the support of CEADS (Center of Environmental Studies and Sustainable Development) during the experiment.

\section{REFERENCES}

ALVES-DE-SOUZA, C.; GONZALEZ, M. T.; IRIARTE, J. L. Functional groups in marine phytoplankton assemblages dominated by diatoms in fjords of southern Chile. J. Plankton Res., v. 30, n. 11, p. 1233 1243, 16 jul. 2008.

BARRERA-ALBA， J. J.; GIANESELLA， S. M .F.; SALDANHA-CORRÊA, F. M. P.; MOSER, G. A. M. Influence of artificial channel in a well-preserved subtropical estuary. J. Coast. Res., v. 50, p. 1137-1141, 2007.

BÉRGAMO, A. L. ; MIRANDA, L. B. ; FONTES, R. F. C. Current measurements and volume transport in the Baía de Guanabara entrance (Rio de Janeiro, RJ). In: Oceanografia e Mudanças Globais. Elisabete de Santis Braga. (Org.). 1ed. São Paulo: Instituto Oceanográfico da Universidade de São Paulo, 2008, p. 357-369.

BRUNET, C.; LIZON, F. Tidal and diel periodicities of size-fractioned phytoplankton pigment signatures at an offshore station in the southeastern English Channel. Est. Coast. Shelf Sci., v. 56, p. 833-843, 2003.

BONILLA, S.; CONDE, D.; AUBRIOT, L.; PÉREZ, M. C. Infuence of hydrology and nutrients on phytoplankton species composition and life strategies in a subtropical coastal lagoon. Estuaries., v. 28, p. 884-895, 2005.

BUCCI, A. F.; CIOTTI, A. M.; POLLERY, R. C. G.; CARVALHO, R.; ALBUQUERQUE, H. C.; TOMIDA, L. Temporal variability of chlorophyll-a in the são vicente estuary. Braz. J. Oceanogr., v. 60, n. 4, p. 485-499, 2012.

CLOERN, J. E. Tidal stirring and phytoplankton bloom dynamics in estuaries. J. Mar. Res., v.49, p. 103-221, 1991.

CONNEL, J. H. Diversity in tropical rain forests and coral reefs. Science., v. 199, p. 1302-1309, 1978.

CUPP, E. E. Marine plankton diatoms of the West Coast of North America. Bull. Scripps. Inst. Oceanogr., v.5, p. 1-237, 1943.

DEMERS, S.; LAFLEUR, P. E.; LEGENDRE, L. Shortterm covariability of chlorophyll and temperature in the St. Lawrence Estuary. J. Fish. Res. Board Can., v. 36, p. $568-573,1979$.
GOOSEN, N. K.; KROMKAMP, J. PEENE, J. RIJSWIJK, P. BREUGEL, P. Bacterial and phytoplankton production in the maximum turbidity zone of three European estuaries: the Elbe, Westerschelde and Gironde. J. Mar. Syst., v. 22, p. 151-171, 1999.

GRIME, J. P. Control of species density in herbaceous vegetation. J. Environ. Manag., v. 242, p. 344-347, 1973.

HANSEN, H. P.; KOROLEFF, F. Determination of nutrients. In: Methods of Seawater Analysis. GRASSHOFF, K.; KREMLING,K.; EHRHARDT. (Ed. Weinheim), New York; Chiester; Brisbane; Singapore;Toronto: Wiley-VCH 1999, Cap 10, p. 159226, 1983.

HANSEN, D. V; RATTRAY, M. New dimensions in estuary classification. Limnol. Oceanogr., v. 11, p. 319-326, 1966.

HANSSON, L-A. Diurnal recruitment patterns in algae: effects of light cycles and stratified conditions. J. Phycol., v. 31, p. 540-546, 1995.

HELBLING, E. W.; PÉREZ, D. E.; MEDINA, C. D.; LAGUNAS, M. G.; VILLAFAÑE, V. E. Phytoplankton distribution and photosysthesis dynamics in the Chubut River estuary (Patagonia, Argentina) throughout tidal cycles. Limnol. Oceanogr., v. 55, p. 55-65, 2010.

HILLEBRAND, H.; DURSELEN, C-D.; KIRSCHTEL, D.; POLLINGHER, U.; ZOHARY, T. Biovolume calculation for pelagic and benthic microalgae. Phycol., v. 424, p. 403-424, 1999.

IGNATIADES, L.; ASSIMAKOPOULOU, E.; GOTSISSKRETAS, O. Phytoplankton size-based dynamics in the Aegean Sea (Eastern Mediterranean). J. Mar. Sci., v. 36, p. 11-28, 2002.

JOUENNE, F.; LEFEBVRE, S.; VÉRON, B.; LAGADEUC, Y. Biological and physicochemical factors controlling short-term variability in phytoplankton primary production and photosynthetic parameters in a macrotidal system (eastern English Channel). Est. Coast. Shelf Sci., v. 65, p. 421-439, 2005.

LEGENDRE, L.; DEMERS, S. Towards dynamic biological oceanography and limnology. Can. J. Fish. Aquat. Sci., v. 41, p. 2-19, 1984.

LEWIS, W. L. Surface/volume ratio: implications for phytoplankton morphology. Science., v. 192, p. 885887, 1976.

LITCHMAN, E.; KLAUSMEIER, C. A. Trait-Based Community Ecology of Phytoplankton. Annu. Rev. Ecol. Evol. Syst., v. 39, n. 1, p. 615-639, 2008.

LUND, J. W. G. Primary production and periodicity in phytoplankton. Verhandl. Intern. Ver. Limnol., v. 15, p. 37-56. 1964.

MACEDO, M.; DUARTE, P.; MENDES, P.; FERREIRA, J. Annual variation of environmental variables, phytoplankton species composition and photosynthetic parameters in a coastal lagoon. J. Plankton Res., v. 23, p. 719-732, 2001.

MACINTYRE, H. L.; CULLEN, J. J. Primary production by suspended and benthic microalgae in a turbid estuary: time-scales of variability in San Antonio Bay, Texas. Mar. Ecol. Prog. Ser., v. 145, p. 245-268, 1996. 
MARGALEF, R. Life-forms of phytoplankton as survival alternatives in an unstable environment. Oceanol. Acta., v. 1, p. 493-509, 1978.

MCGILL, B. J.; ENQUIST, B. J.; WEIHER, E.; WESTOBY, M. Rebuilding community ecology from functional traits. Tren. Ecol. Evo., v. 21, n. 4, p. 178$185,2006$.

MENDEN-DEUER, S.; LESSARD, E. J. Carbon to volume relationships for dinoflagellates, diatoms, and other protist plankton. Limnol. Oceanogr., v. 45, n. 3, p. 569-579, 2000.

MIRANDA, L. B.; CASTRO, B. M.; KJERFVE, B. Classificação dos Estuários In: Princípios de Oceanografia Física em Estuários. IV ed. São Paulo: Editora da Universidade de São Paulo, 2002. Cap. 3, p. 49-97.

MOSER, G. A O.; CIOTII, A. M.; GIANNINI, M. F. C.; TONINI, R. T.; HARARI, J. Changes in phytoplankton composition in response to tides, wind-induced mixing conditions, and freshwater outflows in an urbanised estuarine complex. Braz. J. Biol., v. 72, n. 1, p. 97$111,2012$.

MOSER. G.A.O.; TAKANOHASHI, R.A.; CHAGAS BRAZ, M. de; LIMA, D.T. de; KIRSTEN, F.V.; GUERRA, J.V.; FERNANDES, A.M.; POLLERY, R.A. Phytoplankton spatial distribution on the continental shelf off Rio de Janeiro, from Paraíba do Sul river to Cabo Frio. Hydrobiol., v. 728, p.1-21, 2014.

MURREL, M. C. Phytoplankton and zooplankton seasonal dynamics in a subtropical estuary: importance of cyanobacteria. J. Plankton Res., v. 26, n. 3, p. 371382, 16 fev. 2004.

NASELLI-FLORES, L.; PADISÁK, J.; ALBAY, M. Shape and size in phytoplankton ecology: do they matter? Hydrobiol., v. 578, p. 157-161, 2007.

OLENINA, I. et al. Biovolumes and Size-Classes of Phytoplankton in the Baltic Sea. Baltic Sea Environ. Proc., n. 106, 2006.

PARANHOS, R.; PEREIRA, A. P.; MAYR, L. M. Diel variability of water quality in a tropical polluted bay. Environ. Monit. Assess., v.50, p. 131-141, 1998

PRITCHARD, D. W. The dynamic structure of a coastal plain estuary. J. Mar. Res., p. 33-42, 1956.

REYNOLDS, C. S. Funtional morphology and the adaptive strategies of freshwater phytoplankton. In: Growth and Reproductive Strategies of Freshwater Phytoplankton. Sandgren, C. D. (ed.), Cambridge University Press, 1988. p. 388-433.

REYNOLDS, C. S.; HUSZAR, V.; KRUK, C. Towards a functional classification of the freshwater phytoplankton. J. Plankton Res., v. 24, p. 417-428, 2002.

SEIP, K. L.; REYNOLDS, C. S. Phytoplankton functional attributes along trophic gradient and season. Limnol. Oceanogr., v. 40, n3. P. 589-597, 1995.

SEURONT, L.; SCHMITT, F.; LAGADEUC, Y. Turbulence intermittency, small-scale phytoplankton patchiness and encounter rates in plankton: where do we go from here? Deep-Sea Res. Part I., v. 48, p. 1199-1215, 2001.
SMAYDA, T. J.; REYNOLDS, C. S. Community assembly in marine phytoplankton; application of recent models to harmful dinoflagellate blooms. J. Plankton Res., v. 23, p. 447-461, 2001.

SOURNIA, A. Form and Function in Marine Phytoplankton. Biol. Rev., v. 57, n. 3, p. 347-394, ago. 1982.

SOUZA, A. P. R. D.; BRAGA, E. S.; BERTOTTI, M. On Site Stripping Voltammetric Determination of $\mathrm{Zn}(\mathrm{II})$, $\mathrm{Cd}$ (II) and $\mathrm{Pb}$ (II) in Water Samples of the CananéiaIguape Estuarine-Lagoon Complex in São Paulo State, Brazil. J. Braz. Chem. Soc., v. 23, n. 7, p. 1320-1326, 2012.

STRATHMANN, R. Estimating the organic carbon content of phytoplankton from cell volume or plasma volume. Limnol. Oceanogr., v. 12, p. 411-418, 1967.

SUN, J.; LIU, D. Geometric models for calculating cell biovolume and surface area for phytoplankton. J. Plankton Res., v. 25, n. 11, p. 1331-1346, 2003.

TOMAS C. R. Identifying Marine Phytoplankton. New York: Academic Press, 1997.

TREMBLAY, J.-É.; LEGENDRE, L.; THERRIAULT, J.C. Size-differential Effects of Vertical Stability on the Biomass and Production of Phytoplankton in a Large Estuarine System. Est. Coast. Shelf Sci., v. 45, n. 4, p. 415-431, out. 1997.

UTERMOHL, H. Perccionamento del Metodo Cuantitativo del Fitoplancton. Associación Internacional de Limnologia Teórica y Aplicada Comité de métodos limnologicos, comunicación, v.9, p. 1-39, 1958.

VARGAS, C. A. et al. The relative importance of microbial and classical food webs in a highly productive coastal upwelling area. Limnol. Oceanogr., v. 52, n. 4, p. 1495-1510, 2007.

VERITY, P. G.; ROBERTSON, C. Y.; TRONZON, C. R.; ANDREWS, M. G.; NELSON, J. R.; SIERACKI, M. E. Relationships between cell volume and the carbon and nitrogen content of marine photosyntretic nanoplankton. Limnol. Oceanogr., v. 37, n. 3, p. 14341446, 1992.

VILLAC, M. C.; TENENBAUM, D. R. The phytoplankton of Guanabara Bay, Brazil. I. Historical account of its biodiversity. Biot. Neotrop., v. 10, p. 271-293, 2010.

WETZ, M. S.; HAYES, K. C.; LEWITUS, A. J.; WOLNY, J. L.; WHITE, D. L. Variability in phytoplankton pigment biomass and taxonomic composition over tidal cycles in a salt march estuary. Mar. Ecol. Prog. Ser., v. 320, p. 109-120, 2006.

(Manuscript received 15 November 2013; revised 10 August 2014; accepted 11 August 2014) 